\title{
The Tragic Hero in Rattigan's Adventure Story A Study of His Moral Decline
}

\author{
Professor Saddik Gohar
}

\author{
UAE University, United Arab Emirates
}

\begin{abstract}
According to Aristotle's theory disseminated in The Poetics, the tragic hero should be a man with a towering personality who, due to a certain tragic flaw, undergoes some sort of transformation from prosperity to adversity, which leads to his tragic downfall. This paper explores the moral decline of Alexander, the protagonist of Terence Rattigan's play Adventure Story in the light of Aristotle's concept of the tragic hero and within the context of the play itself.
\end{abstract}

Keywords- Tragic hero; moral decline; metamorphosis; suicide; ambition; violence; Persian; Greek; military; victory; defeat; power

In Rattigan's great play, the hero, Alexander, undergoes a tremendous metamorphosis, which results from a certain tragic flaw ${ }^{1}$-his ambition to achieve the impossible and become a demigod, which- in its turn, brings about his tragic moral decline. In the beginning of the play, the dramatist presents his hero, Alexander, as a promising young man who has an unequal military genius. When Alexander makes his first appearance, we become aware that the ambitious hero has already worked out a strategic plan to invade the Persia Empire. His plan partly makes use of "The Celician Gates" 2 because they are "the most easily defended pass in the world" as he tells the Pythia. Alexander's ambitious plan to conquer the Persian Empire reveals his genius as a military leader. His calculated plan is the result of a deep study of the psychology and military tactics of the enemy. He tells the Pythia: "Speed is the main thing. Asiatics do not understand speed. They expect their opponents to fight by the book of rules". So Alexander is introduced in the beginning as a great leader with a towering personality and this satisfies the first part of Aristotle's definition of the tragic hero.

But, Alexander's ambition to invade the Persian Empire is not an end in itself but it is the beginning of a military career of conquest which will send him all the way from

1 See S.H. Butcher, ed/trans. The Poetics of Aristotle. Macmillan, 1902.

${ }^{2}$ See Terence Rattigan. Adventure Story. London: Samuel French Ltd, 1950.
Macedon to India and back to Babylon. Alexander's dilemma is that he is not satisfied with worldwide expansions, but he aspires to transcend the human boundaries and become a god. During his meeting with the Pythia, the Priestess of Delphi, Alexander said: "I once asked my tutor how a man could become a god and he answered, by doing what is impossible for a man to do". Rattigan, for dramatic purposes, arranges the meeting between Alexander and Pythia early in the play in order to reveal the hero's superhuman ambitions and to prepare the audience for the coming tragedy. In other words, Rattigan, by confronting Alexander with Pythia, allows the hero to unconsciously, uncover his tragic flaw - the strong urge to do the impossible and become a god which will lead to his tragic fall. In this way, Rattigan makes the audience/readers prepared to observe the moral transformation of the hero, which brings about his end.

For dramatic purposes, Rattigan also allows the hero to take his decision to pursue ambitions and become a demigod willingly. Therefore, he will have to pay the price for his mistake later. In Act one, Alexander took his fatal decision to do the impossible and become a god when he was under no pressure. Nevertheless, the Pythia warns him of exceeding his human limits. She honestly advises him to conquer himself before conquering the world, a piece of advice which he will only get its meaning by the end of the play after great suffering. By giving us this background about Alexander, Rattigan shows that his hero has taken a full moral responsibility for his final decision to invade the world and become a god. Such a moral responsibility will force him later to bear the burden of his mistake and he will willingly pay the price for his error through pain and suffering.

Alexander's meeting with the Pythia in the first act of the play reveals that that the hero of the play is an over ambitious young man who has committed his life to achieve his aspiration. In Act one also, Rattigan gives us an ideal image of Alexander. He is figured out as an ideal military leader who wants to conquer the world not for the sake of colonial expansion but because he wants to establish the world-state, which is governed by the mangod "whose word is law". The leader of such a Utopia, as Alexander claims, will devote his life "to the welfare of all his many million subjects". In Alexander's Utopia, 
war does not exist and all forms of oppression should be terminated. He said: "no more war, no more oppressions". But, peace will prevail the whole new world. The new world-state will be democratically governed because Alexander himself has been elected through democratic ways. Therefore, in Alexander's new world, all the other nations such as the Egyptians and the Persians will share the Greeks the same rights and duties. But, only the Greeks will be the leaders of such a world-state: "It will be an Hellenic world .....only national sovereignties will have to be given up". The idea that only the Greeks will be the leaders of Alexander's world-state contradicts with his democratic assumptions and shows that his ideal world-state is built on an illusion.

In spite of his wide ambitions and aspirations to become the leader of the world, Alexander's life-style before conquering Persia, was simple and acceptable by his friends and the army officers. Unlike his father, Alexander does not addict sex or wine and he does not like sleep because these things remind him of his mortality and human weakness: "sex and sleep are the two things in this world that make me most conscious of my mortality". Moreover, Alexander, before his conquest of the Persian Empire, had good relationships with his friends and the army officers. He consults them concerning his future plans and military ambitions. He deals with Cleitus as a father and he treats Parmenion and Philotas as his equals.

But, Alexander starts to change after the conquest of the Persian Empire. He begins to grow into a dictator and forgets all his ideals about the world-state he wants to establish. For the sake of political propaganda and arrogance, he calls himself King of Macedon, Captain General of Greece, Pharaoh of Egypt, King of Babylon, Lord of the lands, King of Persia and Master of the world. This obviously reveals Alexander's love of authority and power which characterizes the beginning of his moral decline. His interest in authority and power turns him into a cruel tyrant. Alexander, who speaks about democracy with the Pythia, gives orders that Bessus, Prince of Bactria, should be executed according to the Persian way. Alexander cruelly rejects Bessus' only request to be executed as a soldier not as a criminal who has violated the law. But, Alexander refused to give Bessus a military execution for political reasons - he wants to convince the Persians to deal with the Greeks not as their invaders but as their lawful masters who protect the Persian law.

Alexander's moral decline becomes clear when the hero adopts the life-style and the finery of the Persians. Now, he stays in a luxurious tent, accepts the ceremonies of the Persian court and has a harem of his own. On the political level, he pursues his colonial conquests not for strategic reasons but for the sake of expansion at the expense of other countries. Nothing can satisfy his hungry appetite for power and domination: "And after India the West and after the West the north - there is plenty yet to do". Alexander's attitude towards military conquest shows his moral decline and change of character. His moral metamorphosis is clearly reflected in the way he deals with political uprisings in the new lands he has annexed. He was greatly bothered by any news about acts of rebellion against his army. Being reported that Oxyartes, a local chieftain leads a series of rebellions against Alexander's army; he just told Ptolemy to cut the head of Oxyartes' captive daughter and "throw him her head as a present".

Alexander's moral decline is equally shown in his changing attitude towards sex and drink. Before conquering the world he avoids these things. But after his conquest of the world, he becomes a sex maniac who seeks sexual pleasure with captive girls such as Roxana. He starts to drink heavily and urges others to get drinks. It is accurate now that Alexander, the great leader whom we meet in the beginning, is changed completely and starts to deal with every thing, even his personal affairs, in a new way. For example, he agrees to marry Roxana for political purposes as he wants to make an alliance with her father, the rebel. But, Alexander's drastic change and moral deterioration could be clearly seen in the way he turns against his closest friends and fellows in the battlefield. He kills Philotas because Philotas refuses to talk about him as a demi-god. He plans to kill Parmenion in a shameful way because he has grown paranoid and jealous of Parmenion who is loved by the people of Babylon. So, when Hephaestion refuses to carry out Alexander's conspiracy against Parmenion, he asks Peradiccas to assassinate his friend Parmenion.

In the later stages of his moral decline, Alexander openly accepts despotism and tyranny as the only possible ways of keeping order in his empire, a premise which runs counter to his democratic views declared early in the play. He said: "you call me a despot, what else can I be? How can this vast Empire be ruled but by despotism?". He even turns his ideals upside down when he shows that democracy leads to chaos and political disorder as in Athens: like Athens with a democratic revolution every year". Alexander's tyranny extends to Cleitus, the old Macedonian soldier who encourages Alexander and stands by his side in all the critical moments of his military career. Alexander kills Cleitus in cold blood, with his own sword because Cleitus opposes him and rejects to show respect to Alexander's wife. Cleitus' murder affirms, beyond all doubts, that Alexander has turned into a brutal monster and a blood shedder. With the murder of Cleitus, Alexander's decline is complete and the play starts to take its downward turn towards the final 
tragedy which we are now fully prepared for.

Even the Queen Mother who is the only one left to give Alexander emotional support is fully aware that the hero will meet his tragic downfall soon. She knows that Alexander cannot go back now because he has paid the price for his failure to conquer himself before conquering the world. He fails to understand that though he is Alexander the Great, he is still a weak human being with limited human capabilities and points of weakness. By the end of the play, Alexander should realize the futility of human ambition. But, he realizes this lesson too late because he was driven by his devil (his tragic flaw) to continue with conquest "until the bitter end" - bitter because, as the Queen Mother warns him, his devil must conquer him. However, Alexander finally realizes the hard lesson; that he should conquer himself first, the lesson which he only learns after great suffering and pain. Learning such a lesson, Alexander burns his own throne and refuses to give the name of his successor. He said in the final moments of his death agonies: "whom shall I condemn to death the adventure is over". With these significant words Alexander ends his life tragically as a great hero who courageously takes responsibilities for his own actions and willingly faces his tragic fall.

\section{REFERENCES}

Butcher, S.H., Ed / Tr. The Poetics of Aristotle. Macmillan, 1902.

Rattigan, Terence. Adventure Story. London: Samuel French Ltd, 1950. 